\title{
ARTISTIC INNOVATIONS ON THE SILVER SHRINE OF ST. SIMEON IN ZADAR
}

\section{IVO PETRICIOLI}

UDC 739.1 (497.5 Zadar) (091),13”

Review

Manuscript received: 01. 04. 1996.

Revised manuscript accepted: 22. 04. 1996.
I. Petricioli

Faculty of Philosophy

Zadar

Croatia

The large silver shrine on the main altar of St. Simeon's church in Zadar, executed in 1380 by Zadar goldsmith Francis of Milan in the repoussé technique, has not been until recently adequately evaluated from the viewpoint of art-history. The author analyses all compositions with figures linking them to the most advanced artistic realisations in Italian painting of the time, $i$. e. the paintings by Giotto and his followers, and affirms that Francis of Milan was acquainted with them. His ouvre was a means by which Giotto's innovations in painting indirectly reached Zadar.

On the high altar of the Church of St. Simeon in Zadar, two large baroque bronze angels bear a gilded silver chest much older than themselves. The cold glitter of the already faded gilt, the worn silver plate, beaten out to the last square inch by the tools of goldsmiths and bearing a legend of figural scenes succeeding one another, cannot help making a strong impression on anyone who looks at it. Medieval mystery surrounds the chest, and it seems to rebuff the rational eye of the expert. Many stories, old and new, are connected with it, and make it difficult to discover what is true, and what is legend.

The chest was made for a well-preserved body which, according to 13th century Zadar tradition, was that of the prophet Simeon, who held the infant Christ in his arms in the Temple of Jerusalem. This is his body, not the one kept in Venice. The Venetian-Zadar dispute over which relic is authentic reflects the fierce rivalry between the two towns, a rivalry which, in the distant centuries of the Middle Ages, contributed to the historical rise of Zadar. The struggles, victories and defeats, and the courage and perseverance of the Zadrans, were in a certain way connected with this body.

The chest itself is much more important for history and the history of art than the relic. It recaptures an important period in the history of Zadar, and not only of Zadar but also of the whole second half of the 14th century. It was then that this powerful city commune, and its inhabitants, struggled for complete independence and economic prosperity, and found that they were the focus of the interests of an ambitious king, Louis of Anjou. The city's role was to become the link between the King's South-Italian possesions and the Polish-Hungarian-Croatian state over which he ruled. The chest was commissioned by his wife, Queen Elizabeth Kotromanić, who was to play an important political role after his death, and to die tragically not far from Zadar, in the Novigrad fortress.

The silverwork itself, rough in detail and magnificent in general impression, which was wrought during three tedious war years through the perseverance of the goldsmith Francis of Milan, who married into Zadar, provides both the ordinary viewer and historian with much of interest, but also with problems. Many books, from the first 17 th and 18 th century his- torical books about the region to the latest historical books and tourist brochures, have been written about the chest. The oldest among them paid particular attention to folk tradition and historical events connected with it. At the end of the last century, however, art analysis came to the aid of historians in their search to understand the real and the seemingly different treatment of goldwork of the various parts of the chest. In the nineteen thirties, new research into the archives threw much new light onto the problem, although recently we have been slightly confused because of awkward interpretations.

In this publication we shall try, as far as we can, to present all available data, analyze the work itself once again, and determine its place in the framework of Croat and European medieval art.

$$
* * *
$$

The chest is rectangular, 1.92 metres long, 0.625 metres wide, 0.71 metres high without the roof. The gabled roof is 0.56 metres high, giving the whole chest a height of 1.27 metres. The front side, which opens, is 0.665 metres high, and the surface of roof is 0.62 metres wide.

The chest is dominated by the saint's reclining figure on the front side of the roof. It is beaten in high relief. The saint lies on his back, with his hands crossed in his lap. His head, with long hair and a long beard, rests on a pillow. He is dressed in a long gown and cloak, which is fastened on his breast by a round clasp. His head and hands are almost fully modelled and have realistic details. They are impressively an old man's hands with marked veins and creases. The hair and beard are rather stylized. The cloak and gown are richly ornamented with plant motifs that imitate decorations on textiles. They were made by punching. The saint lies on a decorated relief with ornaments in the form of leaves. Around his head and on his wrist is the punched inscription in Gothic minuscule sanctus Simeon propheta.

On the front side, which is movable and opens on hinges at the bottom, so that the interior of the chest can be seen, are three compositions, most important in context. They are now separated from each other by convolute columns with capitals and angels' heads. The central composition is the Presentation 


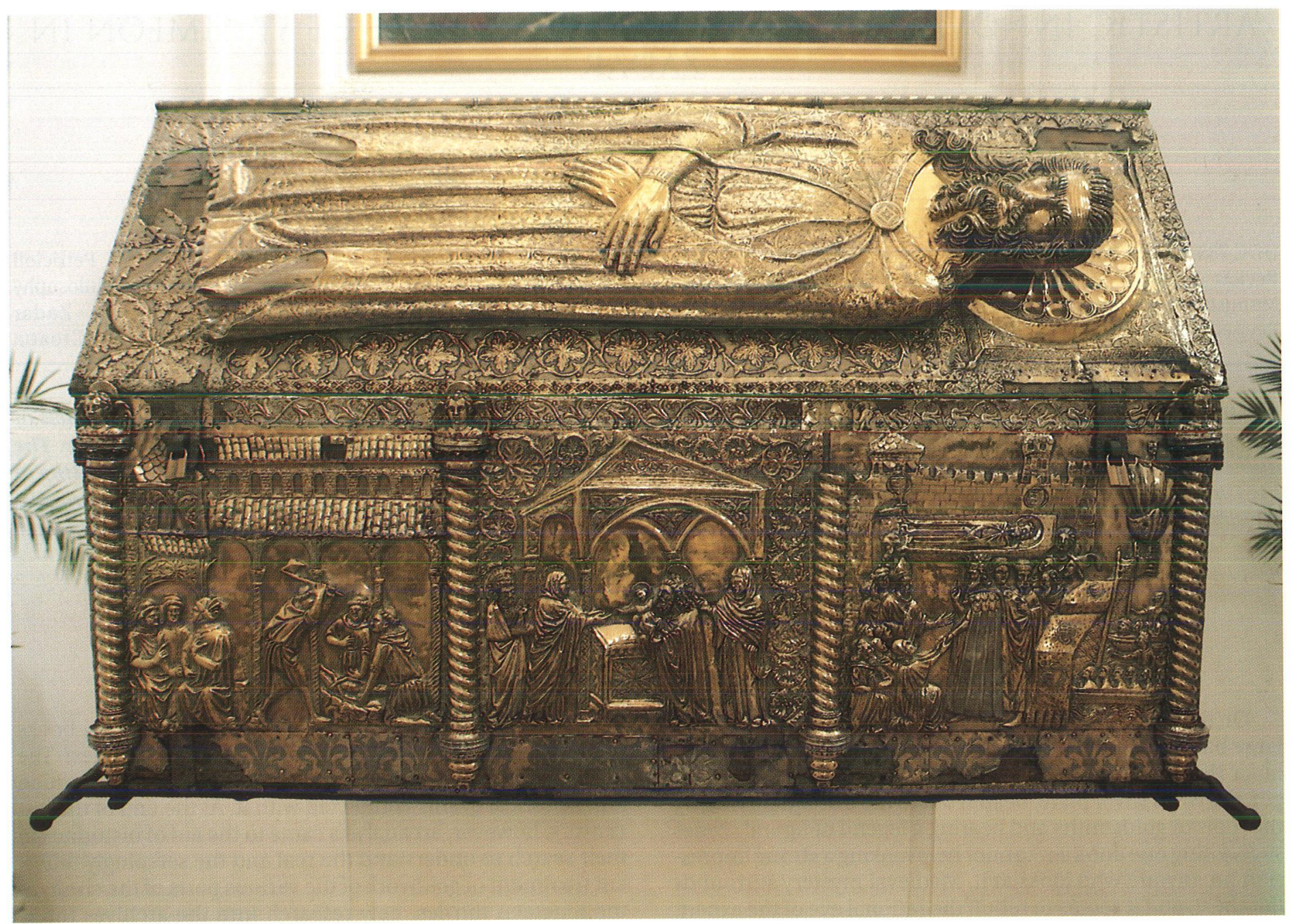

Fig. 1. Zadar, silver shrine of St. Simeon (photo: I. Pervan)

in the Temple (presentatio domini nostri Iesu Christi), which is expressively mentioned in the contract for the chest. Under a ciborium, which rises on four square columns, we see old Simeon taking into his arms the infant Christ. The infant is turned towards his mother, who is still holding out her arms. At the side are two more figures, to the left Joseph holding a pigeon, a votive offering, and to the right the prophetess Anna holding an unrolled scroll in her left hand. The figures are beaten in a much higher relief than on the other compositions (Simeon's figure just out 2.5 centimetres). The scene is very expressive and reveals not only good craftsmanship, but great realism in the presentation of the individual figures. In contrast to those positive characteristics, the artist seems to have had a horror of anything unembellished (horror vacui). All free surfaces are filled in with various, more or less standard gold ornamentation which is found almost everywhere on the chest: vines, leaves and winding rosettes of sinuate leaves.

Meyer established that Francis used as a model the fresco by the then famous painter Giotto in the Scrovegni Chapel (Capella dell'Arena) in Padua. He only eliminated two less important figures shown at the side of the fresco. Bersa noted that the figure of Christ iconographically did not correspond to that on the fresco. On the chest Christ is turned towards his mother, on the fresco he faces Simeon. In this, he resembles a smaller painting today in the Gardner Museum in Boston. It is of a lesser quality than the Paduan fresco, and was once ascribed to Giotto's workshop, though now to Giotto himself. Iconographically it is the same except for the position of the infant
Christ and the number of figures. The shape of the ciborium is different, and resembles Giotto's painting of the same composition in the Peruzzi Chapel in the Church of S. Croce in Florence. Mary and Simeon are behind the columns, while in Padua and on the chest they are in front of them. Two details make the representation on the chest differ from both patterns. Joseph is shown in half-profile (he is in profile on the paintings), and the draperies on the figure of St. Simeon are freer in composition. Those facts indicate that Francis did not directly copy either the fresco or the painting, but probably made use of some drawing which circulated in painters' and sculptors' workshops in those days. To what extent he followed the patterns can also be seen from the columns of the ciborium, on which Francis engraved an ornament of rhombs, which cannot be seen either on the fresco or the painting, where the columns are round and convolute.

The left silver panel holds a relief showing the finding of the body of St. Simeon in a Zadar suburban monastery cemetery, according to a folk tradition retold by Fondra in great detail. The left bottom corner of the relief shows a group of three Rectors. The movements of the Rectors reveal excitement. The left one has a lifted forefinger, the central one entwined fingers of both hands, and the right one is pointing his left thumb over his shoulder at the three monks exhuming the saint's body. The monks are shown under a porch with an arcade of semicircular arches. The left monk, who is swinging a hoe above his head, fills in the space between two columns. The central figure is kneeling and holding a lantern, which 

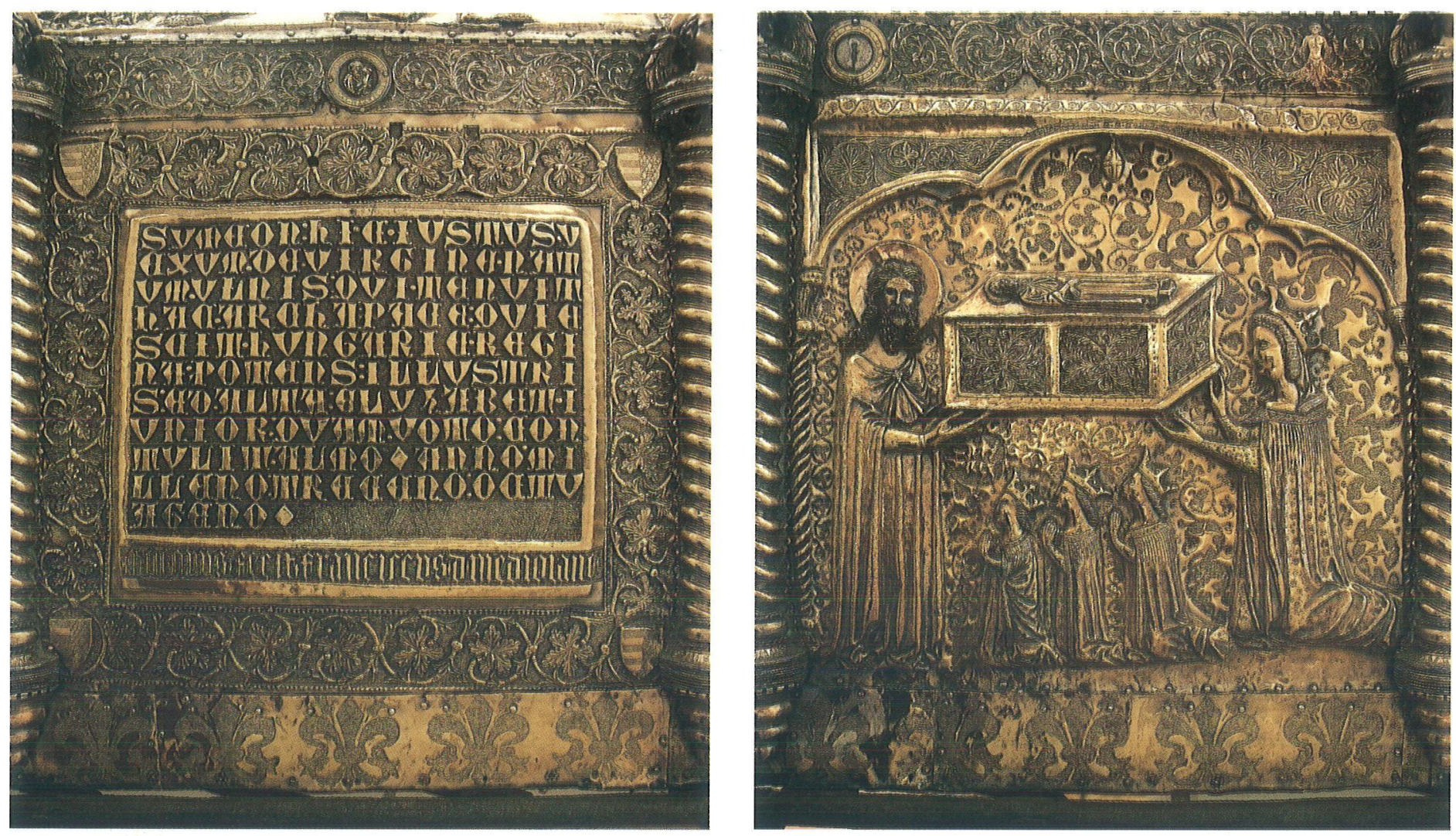

Fig. 2-3. Silver shrine of St. Simeon, details (photo: I. Pervan)

shows that the scene is taking place at night. The third is also kneeling and taking hold of the saint's naked body.

Most interesting from the historical aspect is the scene on the right, which shows the ceremonial entry of King Louis into Zadar harbour. Several authors are of the opinion that Louis came into the harbour by ship. This is not very probable, because he usually came by land. If the scene shows his arrival at the end of 1357, when the peace treaty between him and Venice was signed, then it is certainly not possible. But since the harbour is shown, the scene probably shows him passing through it. Regardless of that, it is a very interesting composition showing an event almost contemporary to the making of the chest. It is unlikely that the goldsmith himself witnessed it, but he knew well where it took place, and also what the King looked like, probably also what Archbishop Nikola Matafar, who did not die until 1367, and some other persons shown here looked like. In the background can be seen the Zadar town walls and gate; there is no doubt that they are the gates in the harbour close to the Church of St. Mary the Great, in which the body of St. Simeon lay until 1570, and after which the gate was named. The walls are shown realistically with engraved stone blocks to illustrate the building technique; they are topped by battlements. Above the town gate is a tower whose openings have characteristic defense shutters. The roof has scale-like tiles. Further to the right, behind the wall, is a second tower with several openings and with a scale-like roof - this was probably the bell-tower of the church, which existed in those days; it was pulled down at the beginning of the 15th century to be replaced by a new one, built by the architect Vidul Ivanov. The walls end with a tower that has two windows and battlements. Above the town gate and on the wall in front of the bell-tower, are the coats of arms of King Louis. The bottom two thirds of the panel are taken up by the scene of the entry. The main figure, King Louis, is placed almost in the middle. The central line of the surface passes right beside him. He is shown in profile, clothed in cer- emonial robes. A long ermine cloak covers his whole body. Only the feet and hands can be seen. On his head is an open crown with fleurs-de-lis. He has long hair and a pointed beard. There are traces of meticulous work on his features, so we can conclude that the goldsmith desired to define Louis faithfully. To the left of the King are five figures kneeling in allegiance and humility. Above them stands Archbishop Nikola Matafar blessing the King; he has a short curly beard. Behind the King are crowded several of his followers. Above these figures is shown the chest of St. Simeon with the figure of the reclining saint, identical to that on the roof of the chest we are describing. To the left, above the head of the Archibishop, is the head of a bearded man in profile; he is turned towards the town gates and is bearing the chest. Above the chest, in that place, flutters a flag on a mast with a cross. Above the group of the King's followers can be seen two heads which at first glance also seem to be part of the group. One is young, and his bending position beside the right end of the chest indicates that he is carrying it. The same can be said of the man with a long moustache and forked beard. From the position of the chest, which is being born into the town through the town gates, Bersa concluded that this scene showed the return of the saint's body into Zadar. During their ten-year-long rule, the Venetians probably removed the body from Zadar, and then, after the King's victory over them, returned it to Zadar at his insistance. This opinion, however, is not confirmed in historical sources. To the right of King's followers are the waves of the sea, and on them two boats with masts flying the King's flags. The silver surface between the boats and the tent is decorated by a network of rhombs, and it is not certain what these are meant to represent. Is the tent part of the boats, or was it erected on the shore? In each boat stands a man pointing at the King. In the boats sit differently dressed townsmen.

The back surface on the chest also shows three scenes separated from each other by convolute columns, ending in ba- 
roque angels' heads. On the central panel, which corresponds to the main composition in the front, is the votive inscription and the goldsmith's signature framed in richly worked vine tracery smaller than that beside the saint's figure on the lid but of the same characteristic modulation. In the corners of the frame are engraved Louis' coats of arms. The inscription field is divided into two parts. The larger part with the main votive inscription has Gothic majuscule letters beaten in high relief, as follows:

\section{SYMEON: HII.C.IVSTVS.Y EXVM.DE.VIRGINE.NAT VM.VLNIS:QVI.TENVIT HAC.ARCHA.PACE.QVIE SCIT.HVNGARIE.REGI NA.POTENS:ILLVSTRI S:ED.ALTA:ELYZABET.I VNIOR: QVAM.VOTO:CON TVLIT.ALMO.ANNO.MI LLENO: TRECENO: OCTV AGENO.}

Below it, in one row, in stylized Gothic minuscule, is punched and engraved the goldmsith's signature:

hoc.opus. fecit. franciscus.d.mediolano.

Such aberrations are known in medieval Latin hexametres. Translated, the inscription runs as follows: "Simeon the Just, who in his arms held Jesus, born of the Virgin, lies peacefully in this chest, which was offered with gentle pledges by the Queen of Hungary, the mighty, glorious and exalted Elizabeth the younger, in the year 1380. This work was made by Francis of Milan." The composition on the left panel is connected to the inscription. It shows Queen Elizabeth presenting the chest to St. Simeon.

The composition is simple and harmonious. It is framed with a stylized elongated triple arch with Gothic cusps, borne on two lateral columns at the edge of the panel. The spandrel is decorated by a vine in very shallow relief. To the left is the standing figure of St. Simeon with the same iconographic characteristics as those of the large figure on the lid of the chest; only his right hand is shown, accepting the chest. Because of the small dimensions, the chest is shown as a simple rectangular box. To the right kneels Elizabeth, ceremonially dressed, shown in profile. A long cloak, edged with a decorated band, and with a fur collar, wraps her whole body and covers her feet. Only her hands are uncovered, and they hold out the chest. The Queen's hair is elaborately dressed, a veil over her head falls about her shoulders, and she wears an open crown with three fleurs-de-lis. Her three daughters are shown in the same position and somewhat more simply dressed; their hands are clasped in prayer, and they are looking at the saint.

The scene to the right of the inscription shows, according to tradition, the illness, or more probably the death, of the Queen's father, the Ban of Bosnia Stjepan Kotromanić. As Jelić correctly observed, the composition has two scenes: the room in which the Ban lies and the church with the saint's chest. The interior of the room with the bed is shown in the usual manner of Gothic paintings, especially Italian ones, which depict the miraculous recovery of the diseased, the birth of the Virgin and similiar scenes. The sick man is old with long hair and a forked beard. At the head of the bed stand St. Simeon, shown in the usual manner. His head is similar to the sick man's. Behind the bed stand two women, who can be seen only from the waist up. To the left is a younger woman with long thick hair; she holds her right hand to her face, and with her left clasps her breast. The woman on the right is older, holding a candle. On the right edge of the scene kneels a boy in rich nobleman's attire with a rolled silk belt around his hips; he faces the other part of the picture and is pointing to the sick man with his right hand. The right part of the picture has a semicircular arch on convolute columns, from which hangs a lantern. Inside the arch is shown the chest of St. Simeon in bad perspective; it is of the same shape as that on the preceding composition, and stands on small posts. Below it kneels, with his hands clasped, a boy dressed like the one on the bench. Many writers agree that this scene shows the death of the Ban of Bosnia under the auspices of St. Simeon, which was to indicate that he was of Catholic faith. It is known that the Bosnian rulers were often accused of the Bogumil heresy, and the Queen desired her father to be considered a Catholic. Jelic goes even further in explaining the two boys' figures; he considers them to represent the Ban's nephews, Tvrtko and Vuk, who came to Zadar to entreat the saint to protect their uncle. But the two figures might in fact represent the same person On other compositions on the chest the same person is known to appear twice, even three times, which is not unusual in the painting of those days, when two or more events are painted simultaneously on the same painting. On the first part of the composition beside the sick man's bed, the boy could be invoking the saint's help, and on the second thanking the saint for his mercy. That would be in accordance with other compositions on the chest.

On the right, shorter side of the chest, by the saint's feet, is a large sailing ship with two masts in a storm. The drama of the situation is very expressively shown. High waves beat the sides of the ship, goods jettisonned by the sailors float on the sea. The front mast is clutched by a monstruos horned demon, while two sailors are trying to secure the sail. One has climbed up the mast and is taking a rope which the other is passing to him; both are obviously in a state of great excitement. A third sailor lifts above his head a large bundle of merchandise, intending to throw it overboard. The captain of the ship is on the elevated stern, holding the helm and giving orders to the sailors. The frightened passengers are in the centre of the boat. Two are looking at the upper left corner where St. Simeon has appeared to save the boat, and the third has bent his head and hidden it in his cloak.

Aristically this composition is rather important. It is also reminiscent of the stone relief on the sarcophagus of St. Peter in the Church of St. Eustorgius in Milan, by Giovanni di Balduccio.

On the other short side is shown an interesting composition with many human figures. The frame is stylized architecture symbolizing a building, almost certainly a church, in which the scene takes place. A large group of ornately dressed people is dominated by the central figure, a woman, also richly dressed, standing stiffly with her left hand pointing to her decoleté bosom. By her stands a man in a noble's attire with a pointed beard and long hair and with an inscription accross his breast. A second man, similarily dressed, with a cloak over his clothes, is pointing to the door with both hands and looking at the woman. Around them other nobles, with caps decorated with long plumes, show signs of surprise. In the right bottom corner we see the saint's chest with its lid raised, so that his body can be seen inside. A woman dressed in the same way as the one already described is taking hold of one of the saint's hands. A wide finger is engraved across her fingers, which could mean that the woman has broken a finger off the saint's hand. All older writers agree that this is the scene when according to tradition, Queen Elizabeth, desiring to beget a male heir, stole a finger from St. Simeon and hid it in her bo- 

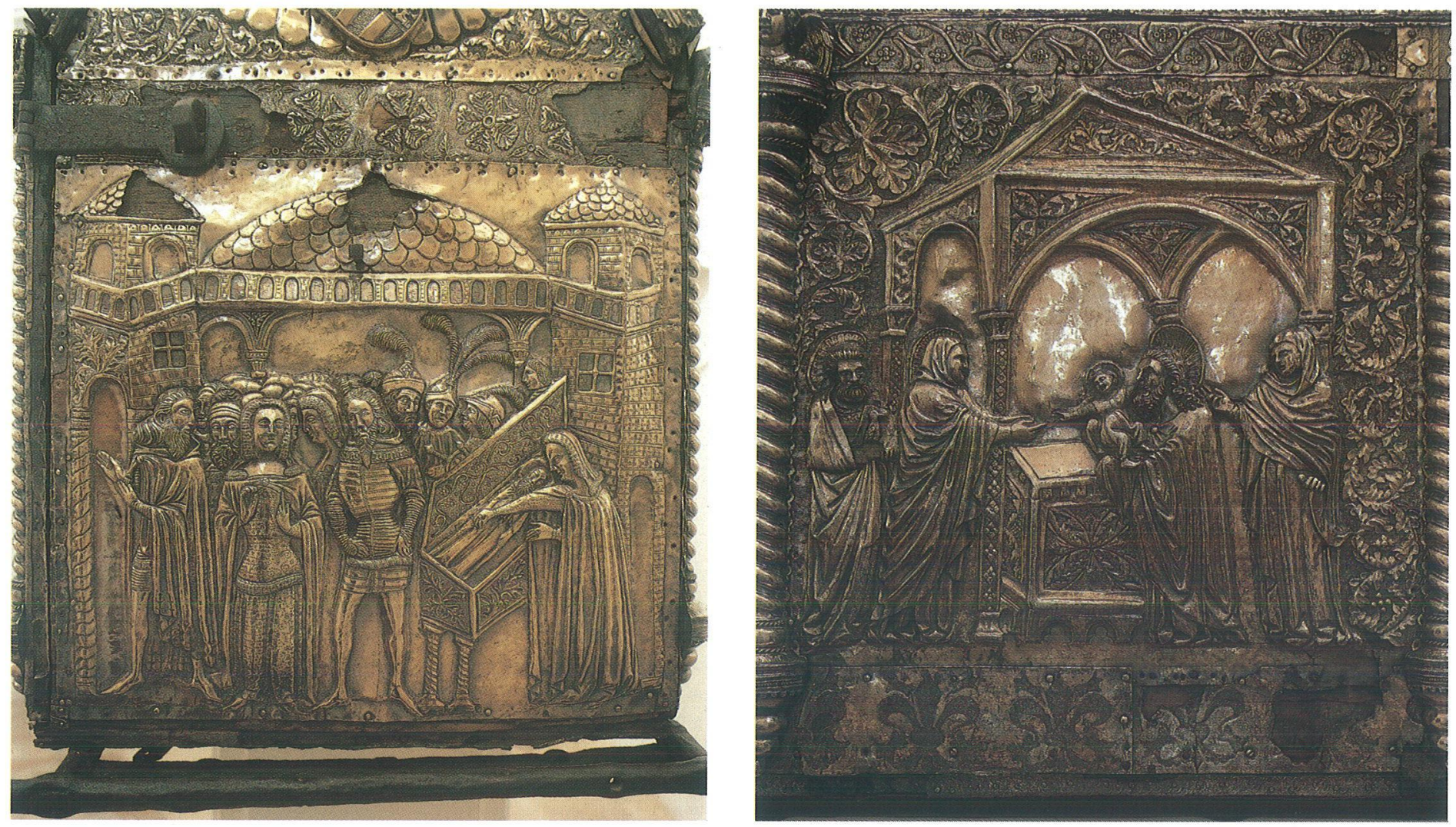

Fig. 4-5. Silver shrine of St. Simeon, details (photo: I. Pervan)

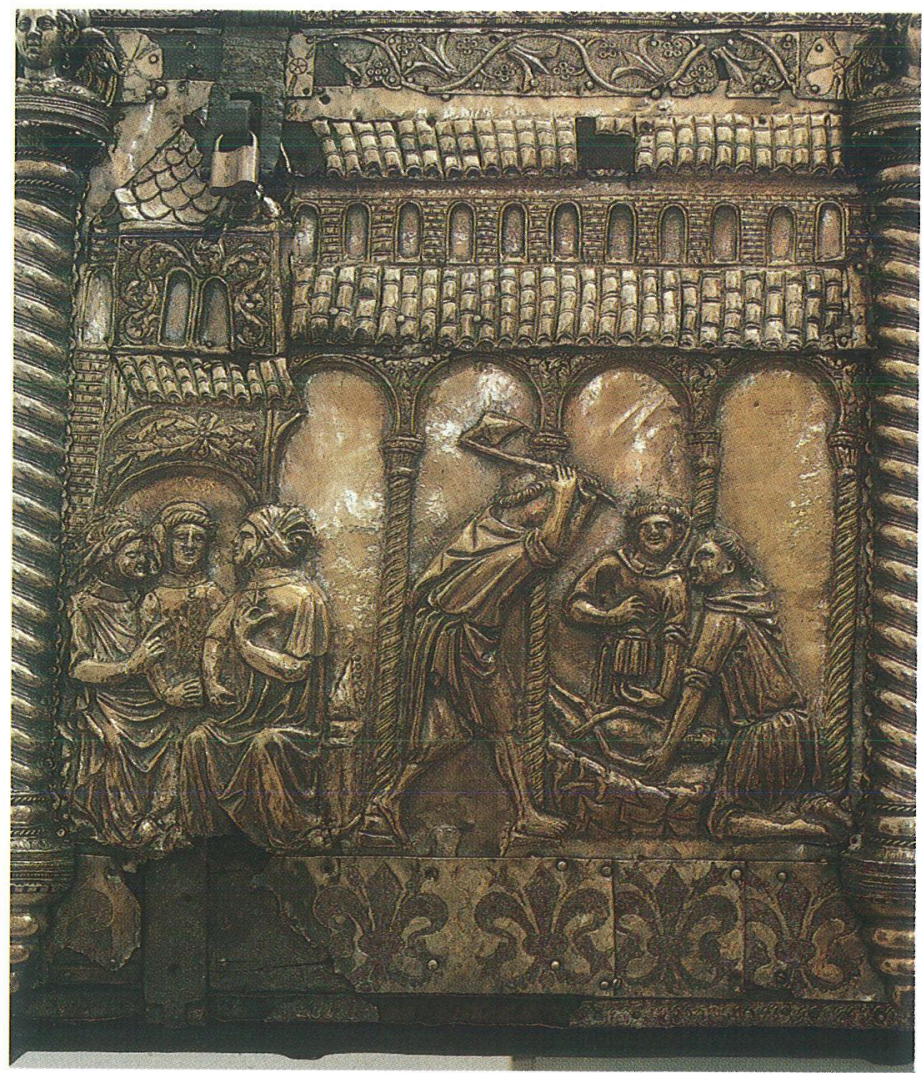

Fig. 6. Silver shrine of St. Simeon, detail (photo: I. Pervan)

som. At the same moment, a wound appeared in her bosom, and, confused, she no longer knew how to get out of the church. In that scene she would be shown twice - once stealing the finger, and a second time, surrounded by her suite, standing stiffly not knowing the way out; the man with the inscription would be King Louis, the one at the door would be showing the Queen the exit.

Above these side scenes rise the triangular gables of the lid. Both are decorated in the same manner, with the coat of arms of King Louis in high relief, shown with all its heraldic accessories. There is the shield with the Hungarian bars and Angevin fleurs-de-lis, a helmet with a crown and a rich cloak. Above the crown rises an ostrich with outspread wings and a horseshoe in its beak. Around the coat of arms are reliefs of acanthus leaves, and beside them the King's initials L. R. (Lodovicus rex).

On the back side of the roof are three compositions showing three different scenes. The first on the left shows the saint's chest in incorrect perspective, standing on four posts. On the left edge is shown a stylized building with arches on the ground floor and arched windows on the first and second floors. Beside the building is a man falling on his back. He is dressed in a long and wide cloak. The goldsmith decorated the cloak with small punched rosettes. Of the under garment, only sleeves and the collar can be seen, which the goldsmith decorated with very fine punching. To the right of the casket is a crowded group of men. The complete figures of two are shown, the bust of another, and only the crowns of the heads of the remaining five. One of the two in the foreground is dressed in the same manner as the man who is falling. He is touching the lid of the chest with his right hand, and his left is held around the other man, who has clasped his hands. His head is turned towards him as if he was saying something. A priest with a tonsure is watching the group. I would like to point out that the same costume is worn by two of the figures - the fallen man and the one who holds his hand out towards the chest. This would indicate that the same person was shown twice, which is, as we have seen, frequent on scenes on the chest. The group in which that person is saying something, watched by the priest, would then be one scene, and the fall of that same person in front of a building, i.e. 


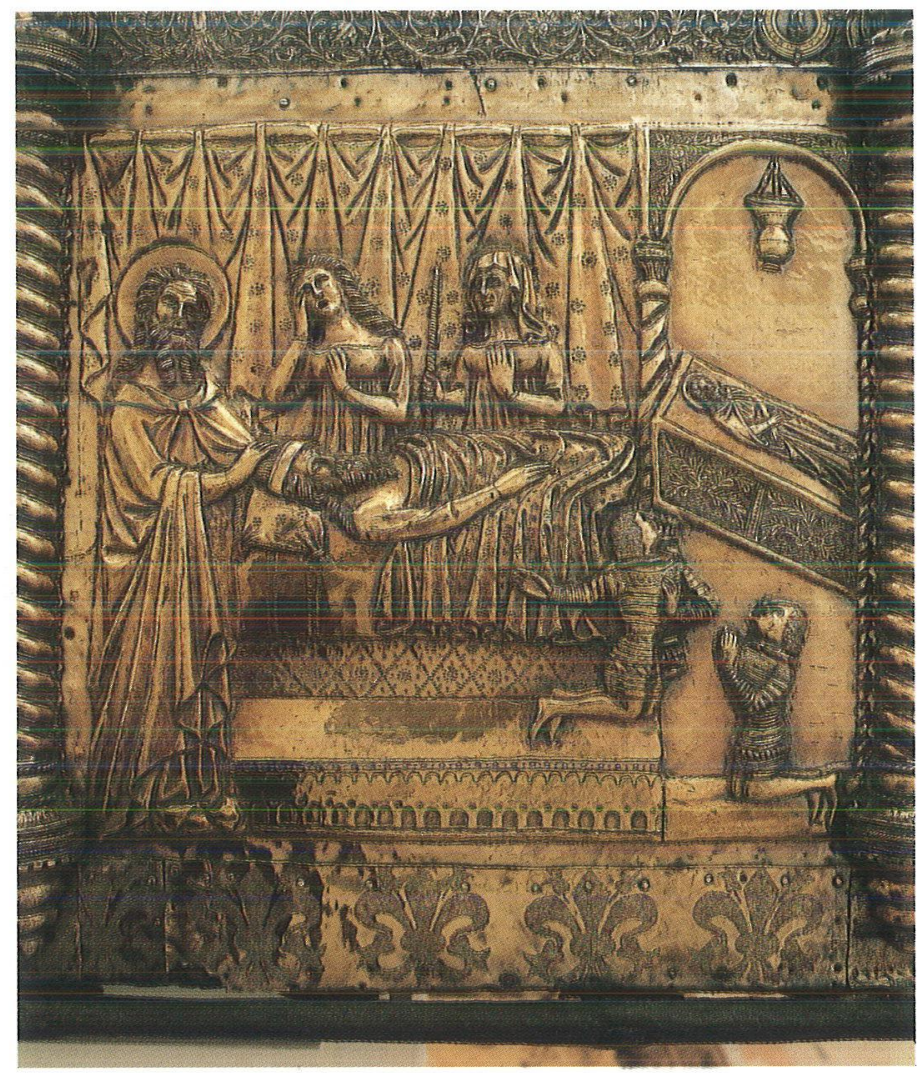

Fig. 7. Silver shrine of St. Simeon, detail (photo: I. Pervan)

outside the church, would be a second. The composition shows either some false oath, or sacrilege committed by that man.

The central composition has only three human figures. It takes place inside a church, which is marked by elements of Gothic architecture. The wide arch with Gothic cusps leans on a convolute column to the left, and on the frame of the composition on the right, and spans almost three fourths of the surface. Below it is shown the saint's chest on posts. One of them has been removed, and before it kneels a man on one knee with goldsmith's tools in his hand. He has turned round and is looking at a younger, bare-headed, close-shorn man, who is kneeling by the column. To the left of the capital can be seen the beginning of a second arch with a Gothic cusp, and in front of it is shown a female figure with her head covered, and wrapped in a long cloak. Behind her is a decoration, also with a Gothic cusp, which cannot be explained. The content of this scene cannot be explained either. The figure kneeling by the post and turning his head seems to represent the goldsmith working on a post that is to bear the chest. This is generally accepted. It could be said that the goldsmith, working in the church, was surprised by the arrival of the young man accompanied by the woman, who kneeled before the chest.

The third composition shows five priests grouped around the saint's open chest. Four are shown down to the waist because they are behind the chest. They evoke signs of surprise by their lively gestures. The fifth is shown complete at the right. He is holding one of the saint's legs in his right hand, and has raised his left to his chin. Older writers consider this scene to show the stealing of one of the saint's legs, which miraculously grew together with the body again when it was returned, while Jelić here also sees a perjurer (in this case a priest) who, as punishment, became crazed.

The inside surface of the front side of the chest, which opens out, so that the saint's body can be seen, shows three of the saint's miracles. The first is depicted in two scenes which are situated inside two arches. On the left there are two men, a younger one with no beard and an older one with long hair and a beard, simply dressed, tightly holding a writhing young man in nobleman's attire, possessed by a demon. The demon, similar to the one in the scene with the boat in the storm, is coming out of the possessed man's mouth. In the second scene the same youth is kneeling with clasped hands before the saint's chest, thanking him for the healing. It seems that the silver plate was later cut on the right edge. The second miracle is also shown in two scenes. On the left there is a small boat on a stormy sea. In it is a man with a long beard and hair, with a tall cap on his head, catching with a hook on a long staff a boy who has fallen into the sea. The body is shown from the back, head down. In the second picture can be seen the saint's chest on posts in incorrect perspective, so that the saint's figure is shown on the side. A woman with a covered head, in a long cloak, is placing the drowned boy on the chest. In the bottom left corner can be seen the same boy brought back to life, kneeling with his hands clasped. These figures showing the same boy were not connected in literature, so that it was wrongly considered that two miracles were shown. However, all three figures have the same features, hair and attire. Especially outstanding is a belt composed of round disks. The arches that frame these two scenes are not shown complete. There is only one column in the middle. The left edge of the panel was probably cut.

The third silver panel shows two scenes concerning a preacher. One the left edge is the pulpit, and above it two pictures. One is a stereotyped illustration of Christ in the grave (imago pietatis), and the second the Virgin with the infant Christ. The priest in the pulpit holds an open book in his left hand, and with his right points to the picture of the Virgin. Most of the surface is taken up by a large bed of the same shape as the one on the scene showing the death of Ban Kotromanić, with a bench at its foot and curtain in the background. In the bed lies the same priest, naked as was then the custom. He is holding his right hand outside the cover, and his left can be made out in the folds of the cloth. Behind the bed stands St. Simeon, with his right hand holding a raised sword. This scene has been explained as the preaching of a heretic priest who attacked some religious teaching concerning the Virgin, so St. Simeon appeared in his dream threatening him with a sword, and steered him to the right path.

No full evaluation has as yet been given of the work of the goldsmith Francis of Milan. Consciously or unconsciously, all who wrote on the subject tried to belittle him. They either denied him the autorship of the greater part of the chest, or called him a craftsman with no imagination or invention.

This began with Meyer, who gave Francis a subordinate role, ascribing all the "Giottesque" reliefs of higher quality to another greater artist. As we have already said, Meyer did not know the complete text of the contract about the making of the chest, and it is from a careful reading of that contract that analysis must start. When it was signed, before both sides, the goldsmith and the Queen's representatives, there was a paper model of the chest, with drawings of all the details. Had that model not been made by Francis but by someone else, this would have been noted in the text of the contract, which is rather detailed. For instance, the contract for the tombstone of Archbishop Nikola Matafar, which had to be carved by Paul of Sulmona in 1386 in Zadar, states that the plan was made by the painter Menegello. In the 1398 contract for building the 
vaults of the sacristy in Zadar Cathedral, it is stressed that the representatives of the Cathedral gave the plan to the builder. The plans for the decorations to be carved in wood in 1486 by Master Ivan Petrov of Korčula in the hall of the mansion belonging to the Zadar noble Saladin Soppe were made by the notary Jeronim Vidulić. As the contract for the chest does not say who made the plan, there is no doubt that it was made by Francis himself. This already proves his authorship. Praga thought the same. According to him, the differences in execution, as we already noted, were the result of the long time the work took and of the fact that the goldsmith got the silver to work on in instalments, so that the chest was not made in one stretch. Although he could have taken on assistants because of the urgency of the job, we know from documents that he took on only one apprentice and one trained goldsmith who was engaged at the end of work. We must add the important fact that Francis worked with more care on those compositions which were more important in content and more exposed to the eye. The relief on them is deeper; for example, on the main composition, the Presentation in the Temple: it stands out 2.5 centimetres. The stiffness in modellation and the roughness and clumsiness in some details disturbed Meyer and others so much that they ascribed whole compositions to less skilled assistants of the main master. Such characteristics, however, are less obvious on the compositions of "a higher quality". This can especially be seen in the modellation of hands. The iconography, i.e. the number of figures on a composition, also conditioned work.

When analyzing a work of art, several factors must be borne in mind; the time in which the work was made, the general art achievements of that time, and the artist's aims and skill. We must consider what the artist, in relation to his time and milieu, desired, and what he could achieve. In the case of Francis, we can make out what he desired from the drawings of the compositions. They are recognizable in the compositions and not difficult to distinguish. What he could achieve can be clearly seen on the surface of the silver upon which he worked. But more about this later.

Let us first analyze the figural compositions, or to be more explict, their draughtsmanship. As we have seen, the main composition is a copy of Giotto's fresco in Padua, or of some draft that reproduced Giotto's interpretation of the presentation in the Temple. We shall also discover characteristics of Giotto's draughtsmanship, his artistic language in all other compositions. This is sometimes more, sometimes less apparent, because the author of the drawings, Francis - as we suppose - had to create the compositions himself. There were certainly some patterns to follow: for instance the ship in the storm, the rooms with a bed, motifs often found in hagiographic scenes of the time. Saints miraculously save ships, heal the diseased, save the souls of the dying. But the specific content of some episodes connected with St. Simeon in Zadar and with the chest made it imperative for Francis to rely on his own resources. His drawings, treatment of the human figure and use of space are on the level of Giotto's innovations, and completely correspond to the painting of Giotto's followers.

Perspective is supplied by simple use of foreground, middle ground and background. A good example is Louis' entry into Zadar: in the foreground there is a group of figures, in the middleground the chest of St. Simeon and the heads of its bearers, in the background the town wall with towers, and the bell-tower. The scene showing the death of Ban Kotromanić has St. Simeon with the boy invoking aid in the foreground, beyond him the bed with the sick man, and beyond again, the two women in front of the curtain (in silver, this perspective does

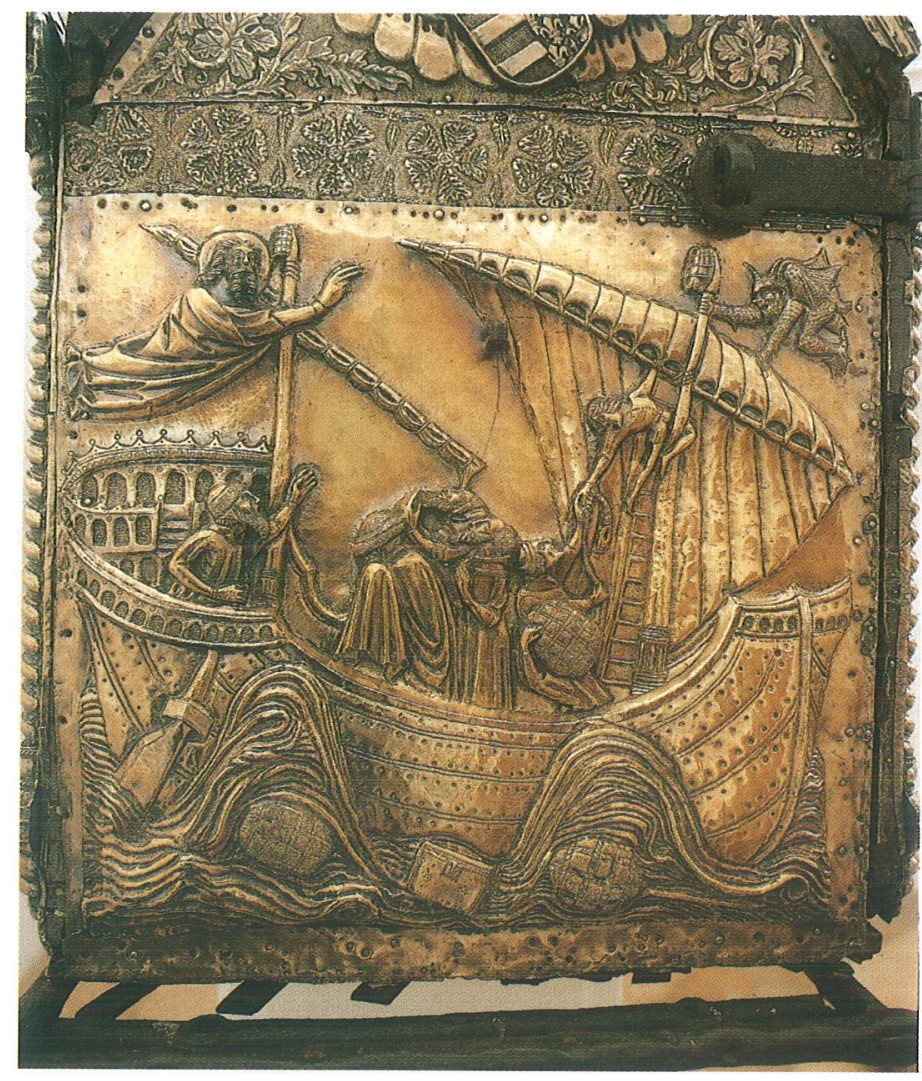

Fig. 8. Silver shrine of St. Simeon, detail (photo: I. Pervan)

not come so clearly to expression; it is more noticeable in the drawing). Giotto, and painters of the Trecento, in general used reduced architecture to connect exteriors and interiors. This was already found on older Byzantine and Romanesque painting, but the painters of the Trecento worked in a new manner, trying to solve problems of perspective and thus create an illusion of space. We also notice such attempts at perspective on compositions on the chest. When Francis shows the saint's older sarcophagus, either standing on small posts or without them, three of its surfaces are always showing. The illusion of space is also sought, rather clumsily, it is true, in the way some scenes merge from one plane into another. For instance, the monks exhuming the saint's body are in front of the arches of the porch, and the saint's body, i.e. its legs, are in the second plane behind the column. On the scene of Louis' arrival the casket, which is being carried in the middleground, enters into the town gates which are in the background. On Francis's compositions showing the interior of the church, we see columns and arches, i.e. the beginning of two arches above a column. They do not represent frames for the scene, as Francesca Delcroix thought in her reconstruction, but serve to evoke the interior of a church with a nave and two aisles, as was the Church of St. Mary Maior in which the relic was kept. This can be well seen in the composition showing the goldsmith, where the kneeling youth is shown in front of the column, and the woman accompanying him behind it.

The composition showing the donatress, more representative than narrative in character, did not demand the elaboration of space. It is symmetrical: to the left stands the saint, to the right kneels the Queen, in the middle is the casket, and below it are the three figures of the kneeling princesses. The central dividing line of the scene runs through the one in the middle. The composition is framed with a symmetrical Gothic frame. The symmetry brings out even more the asymmetry of 
the arches and columns mentioned earlier, which mostly appear on narrative compositions. That asymmetry reflects a "Giottesque" manner of painting, and is done consciously.

The people on Francis compositions have very varied characteristics. There are older and younger persons of both sexes, shaved men whose faces are worked over with goldsmith's tools, bearded men with small pointed beards, with full long or short beards, or with long forked beards. The features are also varied, and so are facial expressions. They resemble caricatures in several places in the silverwork. The gesticulation is realistic, expressive. We have already pointed out the group of three Rectors on the scene showing the exhumation of the saint's body. The gesture of the one pointing over his shoulder at the monks is identical to the gesture of the Virgin showing St. Francis to the infant Christ on the fresco in Assisi by Pietro Lorenzetti. Analyzing the iconography, we notice gestures full of expression in figures on all the compositions. Especially expressive are those on the scene showing the ship in the storm, in the Miracle with the Leg and the Punishment of the Perjurer. The clothes are also clearly differentiated. We can distinguish between simple, plebeian clothes, for instance on the two men holding the youth possesed by a demon, the attire of prominent citizens, which is rather different in cut and form, and noblemen's attire, which is made of stiff embroidered fabrics and fur.

We need not specially stress that these are also forms of direct narration, "plebeian" as it is usual to call it, so characteristic of Giotto and his followers.

Francis' attempt at realism can be clearly seen on the figure of St. Simeon on the lid of the chest. Here we can talk about sculptural realism. The head is given in full plasticity, and the body and the hands in shallower relief, which is usual on reliefs on tombstones. Analyzing the head, we can see stylization in the strands of hair, which reminded Francesca Delcroix of a stone sculpture in Verona. As far as that is concerned, Francis could also have got inspiration from the relief on the older stone sarcophagus in which the relic used to be kept. In comparison with reliquaries in the form of a bust, which have been preserved from approximately the same period in Zadar and are by local goldsmiths, the saint's head shows a much higher quality in the realistic presentation of detail. There is also great realism in the modellation of the hands. They are the hands of an old man with faithfully reproduced details. Here, as on the head, the goldsmith was able to show his full skill in modellation because of the greater dimensions. When the saint's hands are compared with reliquaries in the form of hands of which there are a lot in Zadar, they show a higher quality.

In spite of those positive qualities, in several places Francis shows himself to be a naïve craftsman, at first glance not up to his task. Unused to similiar work, he considered tiny decorations more valuable than the figures in the compositions so that he introduced various plant ornaments, in relief or punched, into the more important compositions. The saint's figure is surrounded by a vine in relief, and his clothes are filled in with motifs imitating textile decorations. The Presentation in the Temple is surrounded by vines. Plant motifs fill in the background of the composition showing the donatress. Various tendrils can also be seen on parts of the architecture, without any logical justification. Some irregularities in the scenes must also be mentioned, which can be explained by the work of some less skilled assistant, for instance the varying heights of the columns in the scene of the man possessed, the shape of the pulpit in the scene with the heretic preacher, etc.

But today, when we are trying to evaluate and revalorize spontaneous original artistic expression more truly, these naïve craft interventions may be considered to have specific artistic value of their own.

In conclusion we must stress again the close links between Francis's work and Giotto's painting. 14th century painting in Dalmatia followed completely the painting of Venice. In Francis's time it was in the shadow of Paolo Veneziano, and Paolo was the first painter to introduce just a breath of the Gothic into traditional venetian Byzantine art. The patterns for Francis's silverwork compositions are much more progressive than the other works of those days in Dalmatia. Thus Giotto's art came to Dalmatia indirectly, through Francis's reliefs in silver, and that is the great value of his work.

\footnotetext{
* This article is a part of the author's book "St. Simeon's Shrine in Zadar"
}

Literature:

VLADIMIROVICH LUCA, Z̈ivot Svetog Sime Zadranina (The Life of St. Simeon of Zadar), Venice 1765 (56 pages).

FARLATI DANIELE, Illyricum Sacrum, vol. V. Venice 1775, p. 162.

P(arma) G(iuseppe), Storia della sacra reliquia del santo Simeone Profeta esistente in Zara, Zadar 1819 (54 pages)

SCOPINICH GIOVANNI, Memorie sulla insigne reliquia di S. Simeone g. prof. esistente nella città di Zara racolte da un sacerdote addetto al servizio della chiesa del Santo, Zadar 1836.

KUKULJEVIĆ SAKCINSKI IVAN, Izvjestje o putovanju po Dalmaciji (Report on Travels in Dalmatia), Zagreb 1854, p. 7.

FONDRA LORENZO, Istoria della insigne reliquia di San Simeone profeta che si venera in Zara, Zadar 1855 (396 pages).

EITELBERGER VON EDELBERG RUDOLF, Die mittelalterlichen Kunstdenkmale Dalmatiens, Vienna 1861, pp. 48-52.

BIANCHI CARLO FEDERICO, Zara cristiana Vol I, Zadar 1877, pp. 334-356.

JACKSON T. G., Dalmatia, the Quarnero and Istria, Vol I, Oxlord 1887, p. 318.

MEYER ALFRED GOTTHOLD, Szent Simon Ezüstkoporsòja Zárában, Budapest 1894.

SABALICH GIUSEPPE, Guida archeologica di Zara, Zadar 1897, pp. 350-356.

BRUNELLI VITALIANO, "Di un nuovo libro sull'arca di San Simeone", Il Dalmata, A. XXXIII, no. 57 (June 20, 1898).

JELIĆ LUKA, "Zadarska raka Sv. Šimuna Bogoprimaoca" (The Shrine of St. Simeon in Zadar), Glasnik matice Dalmatinske, year I (1901-02), pp. 271$283,370-396$

BRUNELLI VITALIANO, "Una nuova scoperta nell'arca di San Simeone"; Il Dalmata, A. XLIIl, no. 65 (august 8, 1908).

BRUNELLI VITALIANO, Storia della città di Zara, Venice 1913, pp. 421-428. 
TRAVASINI L. (BERSA GIUSEPPE), "Peregrinazioni d'arte, S. Simeone”, L'aquila del Dinara, 1923, no. 23 (March 20, 1923), no. 25 (March 27, 1923), no. 27 (April 3, 1923).

BERSA GIUSEPPE, Guida storico - artistica di Zara, Trieste 1926, p. 98 and onwards.

PRAGA GIUSEPPE, "Documenti intomo all'arca di San Simeone in Zara e al suo autore Francesco da Milano", Archivio Storico per la Dalmazia, Vol XIII, Rome 1932.

NOVACH MARIO, San Simeone Guisto e profeta, Zadar 1932.

PRAGA GIUSEPpE, "La suppellettile serica ed aurea del'arca di San Simeone in Zara", Archivio Storico per la Dalmazia, Vol XIII, Rome 1932.

CECCHELLI CARLO, Zara, catalogo delle cose d'arte e antichità, Rome 1932, pp. 107-116.

OŠTRIĆ GRGO, Zlato i srebro Zadra (The Gold and Silver of Zadar), catalogue to exhibition, Zagreb 1951, pp. 29-32.

Zlato i srebro Zadra, introduction by Miroslav Krleža, Zagreb 1951.

GUŠIĆ MARIJANA, "Profani tekstil u raki Sv. Šimuna u Zadru" (Profane textiles in the tomb of St. Simeon in Zadar), Radovi Instituta Jugoslavenske akademije u Zadru 11-12, Zadar 1965, pp. 229-268.

PETRICIOLI IVO, Zadarsko zlatarstvo (Goldwork of Zadar), Belgrade 1971.

GRGIC MARIJAN, Zlato i srebro Zadra i Nina (The Gold and Silver of Zadar and Nin), Zagreb 1972, pp. 174-178.

DELCROIX-MAOVAZ FRANCESCA, "Francesco da Milano e l'arca di San Simeone a Zara", Commentari III, July-September 1970, pp. 185-197.

PETRICIOLI IVO, "Opis Zadra iz godine 1494" (Description of Zadar from 1494), Zadarska revija 15/1966, no. 3, pp. 205-208.

PETRICIOLI IVO, "Likovna umjetnost renesanse u Zadru” (Renaissance Art in Zadar), Zadarska revija 18, 1969, no. 5, pp. $371-372$.

GUŠIĆ MARIJANA, Perizom u zadarskoj raki Su. Šimuna, annual edition of the Balkanološki Institut BALCANICA VIII, Beograd, 1977, pp. 145-188.

PETRICIOLI IVO, Zapažanja o škrinji Su. Šimuna u Zadru, "Radovi Filozolskog fakulteta u Zadru", 15-16, Zadar 1976.

PETIRICIOLu IVO, Škrinja Su. šimuna u Zadru (St. Simeon's shrine in Zadar), Zagreb 1983.

\title{
LIKOVNE INOVACIJE NA SREBRNOJ ŠKRINJI SV. ŠIMUNA U ZADRU
}

\author{
SAŽETAK
}

Velika srebrna škrinja s relikvijom Sv. Šimuna u Zadru, ukrašena nizom figuralnih kompozicija, koju je 1380. godine izradio zadarski zlatar Franjo iz Milana po nalogu kraljice Elizabete, žene ugarsko-hrvatskog kralja Ludovika Anžuvinca, nije do u zadnje vrijeme pravilno vrednovana sa stanovišta povijesti umjetnosti. Dosta se pisalo o ikonografiji reljefnih kompozicija $\mathbf{i}$ isticala se njezina povijesna vrijednost $u$ kontekstu onodobnih političkih zbivanja u Hrvatskoj. Rad Franje iz Milana se dosta potcijenjivao, bilo da se njemu pripisivao manji dio rada na škrinji, a najbolje dijelove pripisivalo nekom nepoznatom dobrom zlataru, bilo da se znatno isticala uloga njegovih pomoćnika.

Nakon što je opisao škrinju i sadržaj kompozicija na njoj, autor analizira likovne osobine škrinje od zlatarske tehnike do povijesnoumjetničkih vrijednosti figuralnih kompozicija. Prema tekstu narudžbe za škrinju od 05. VII. 1377. koja se sačuvala u zadarskom notarskom arhivu, doznajemo da je Franjo predočio naručiteljima, zastupnicima kraljice Elizabete, model škrinje na papiru (in carta bombicina) s nacrtanim kompozicijama, što dokazuje da ih je on sam izradio. Ta činjenica treba biti osnova pri analizi reljefnih kompozicija na škrinji. Treba zanemariti pokoju nespretnost pri obradi detalja, preveliku upotrebu zlatarskih ukrasa (biljnih i geometrijskih motiva), grubost u oblikovanju što je rezultat izvedbe u tehnici iskucavanja, i promatrati zamisao, "crtež" pojedine kompozicije. Lako se uočava da taj "crtež" ima sve osobine slikarstva Giotta i njegovih sljedbenika (pokušaj rješavanja treće dimenzije, realizam u izrazu i pokretima ljudskih likova, individualizacija pojedinih ličnosti fizionomijom i kostimom i sl.). Franjo je glavnu kompoziciju "Prikazanje u hramu" izradio prema Giottovoj freski u kapeli Scrovegni (Capella dell'Arena) u Padovi, dok je druge, nepoznate u uobičajenoj ikonografiji, morao sam stvarati po narudžbi. Sadržaj većine kompozicija nije nigdje drugdje likovno obrađivan i Franjo nije mogao imati uzore. Trebalo je prikazati svečeva čuda po lokalnoj zadarskoj tradiciji i legendama te dogadaje vezane uz naručitelje: kraljicu Elizabetu i njezinog muža kralja Ludovika. U tome je prava vrijednost tog zlatarskog djela, tim više kad ga se usporedi s drugim zlatarskim radovima is djelima drugih grana likovne umjetnosti kasnog srednjeg vijeka na našem primorju i šire. Predlošci za Franjine zlatarske figuralne reljefe znatno su napredniji od onoga što su slikari tog vremena ostavili u Dalmaciji. Tako je Giottova umjetnost stigla $u$ Zadar posredno, putem Franjinih srebrnih reljefa. 
